\title{
ISOLATED MATERNAL HYPOTHYROXINEMIA AND ITS PERINATAL OUTCOME IN NORTH MACEDONIA
}

\author{
Maja Avramovska ${ }^{1}$, Borislav Karanfilski ${ }^{2}$, Goran Dimitrov ${ }^{3}$, Elena Dzikova ${ }^{3}$, \\ Ana Daneva Markova ${ }^{3}$, Marija Hadzi Lega ${ }^{4}$, Gligor Tofoski ${ }^{3}$ and Aleksandar Sikole \\ ${ }^{1}$ Dr. Trifun Panovski Clinical Hospital, Bitola, North Macedonia; \\ ${ }^{2}$ National Committee for Iodine Deficiency, Ministry of Health, Skopje, North Macedonia; \\ ${ }^{3}$ Department of Gynecology and Obstetrics, Faculty of Medicine, Ss. Cyril and Methodius University of Skopje, \\ Skopje, North Macedonia; \\ ${ }^{4}$ Danat al Emarat Hospital for Women and Children, Abu Dhabi, Emirate of Abu Dhabi; \\ ${ }^{5}$ Department of Nephrology, Faculty of Medicine, Ss. Cyril and Methodius University of Skopje, Skopje, \\ North Macedonia
}

SUMMARY - Isolated maternal hypothyroxinemia (IMH) is defined as the presence of low maternal total thyroxine (TT4) level in conjunction with normal maternal thyroid-stimulating hormone (TSH) level. The aim was to investigate whether IMH is associated with adverse pregnancy outcome in North Macedonia. Dried blood spot samples were obtained from 359 pregnant women meeting the inclusion criteria and analyzed for TT4 and TSH. Postpartum data were entered from their medical histories. Out of 359 women, $131(37.42 \%)$ belonged to IMH group. There were statistically significant differences in birth weight $(\mathrm{p}=0.043)$, intrauterine growth restriction (IUGR) $(\mathrm{p}=0.028)$, Apgar score at $1 \mathrm{~min}<7(\mathrm{p}=0.018)$ and cesarean section for dystocia/disproportion $(\mathrm{p}=0.024)$ between the IMH and normal thyroid function $(\mathrm{NTF})$ groups. In regression analysis, TSH was a significant variable predicting Apgar score $(\beta \mathrm{st}=0.05597, \mathrm{p}=0.047)$, body mass index predicting birth weight $(\beta$ st $=0.02338, \mathrm{p}=0.045)$ and TT4 predicting small for gestational age/IUGR $(\beta \mathrm{st}=-0.089834, \mathrm{p}=0.029)$ in IMH group. TT4 was a strong predictor of birth weight $(\beta \mathrm{st}=-0.004778$, $\mathrm{p}=0.003)$ and premature delivery $(\beta \mathrm{st}=0.028112, \mathrm{p}=0.004)$ in NTF group. The impact of IMH in pregnancy remains controversial. IMH was associated with an increased maternal BMI and higher birth weight of neonates. Overweight could be a potential risk factor for thyroid dysfunction in pregnant women, and specifically IMH. The worst fetal outcome was seen in IMH mothers examined in second trimester. We found TSH, TT4 and BMI to be strong predictors of perinatal outcomes.

Key words: Isolated hypothyroxinemia; Perinatal outcome; Low birth weight; Preterm birth; Obesity

\section{Introduction}

A new controversy called isolated maternal hypothyroxinemia (IMH) arises in endocrinolog $y^{1}$, while in the meantime there is still a well-known debate about the recommendation for thyroid dysfunction screening during pregnancy. IMH defined as the presence of

Correspondence to: Maja Avramorska, MD, Filip Vtori Makedonski 37/4/26, 7000 Bitola, North Macedonia

E-mail: dr.avramovska@gmail.com

Received August 19, 2020, accepted September 25, 2020 low maternal total thyroxine (TT4) concentration in the lower $5^{\text {th }}$ or $10^{\text {th }}$ percentile of the pregnancy related reference range, in conjunction with normal maternal thyroid-stimulating hormone (TSH) has recently been in the focus of interest ${ }^{2}$. IMH during early pregnancy is associated with an increased risk of placental abruption, gestational diabetes, macrosomia, and preterm delivery ${ }^{3}$.

The causes of IMH have not been completely revealed, but the etiologies include iodine deficiency, obesity, and iron deficiency. Imbalance between the 
pro- and anti-angiogenic factors could also be a factor, such as pro-angiogenic placental growth factor (P1GF) or anti-angiogenic soluble FMS-like tyrosine kinase-1 (sFlt) and vascular endothelial growth factor (VEGF), both important pregnancy-specific angiogenesis regulators ${ }^{4,5}$. Obesity has also been recently associated with low free thyroxine (FT4) levels through incompletely understood mechanisms 5 .

The 2011 guidelines for the management of thyroid dysfunction do not recommend universal screening of healthy women for thyroid dysfunction before pregnancy ${ }^{2}$. Therefore, the aim of our study was to investigate whether IMH is associated with adverse pregnancy outcome in a pregnant population in the Republic of North Macedonia.

\section{Subjects and Methods}

\section{Subjects}

A total of 359 pregnant women meeting the criteria were enrolled and divided into three groups on the basis of gestational weeks, excluding women with twin pregnancy, personal history of chronic disease (hypertension, cardiac disease, and diabetes), as well as cigarette smokers and those with known thyroid disorders. They gave birth at the Department of Gynecology and Obstetrics in Skopje.

\section{Laboratory tests}

From April to July 2017, a sample of five drops of heparinized blood $(5 \mathrm{~mL})$ was obtained from each woman and applied to a special type of filter paper. The next phase was drying of the samples for 24 hours and keeping them at constant temperature of $-20{ }^{\circ} \mathrm{C}$. Dried blood spot (DBS) samples were analyzed for TSH and TT4 by time-resolved fluoroimmunoassay method (GSP 2021-0010; PerkinElmer, Turku, Finland) at University Children's Hospital, Zurich, Switzerland. Weight and relevant dietary factors were determined by a questionnaire, and body mass index (BMI) was used to classify maternal weight status.

\section{Diagnostic criteria for thyroid dysfunction}

Study women were divided into three groups depending on the trimester of pregnancy at the time of sampling, as follows: first trimester (up to 12 gesta- tional weeks (g.w.)), second trimester (12-28 g.w.) and third trimester (28 g.w. to the end of pregnancy). According to the American Thyroid Association (ATA) guidelines for diagnosis and management of thyroid disease during pregnancy and postpartum, the assay specific reference values for TSH and TT4 were adapted by trimester and gestational weeks at 0.1 3.0/3.7 $\mathrm{mIU} / \mathrm{L}$ and 65/97.5-165/247.5 $\mathrm{nmol} / \mathrm{L}$, respectively ${ }^{6}$. We recorded TSH and TT4 matching values or deviations according to the ATA reference values (based on g.w.).

\section{Diagnostic criteria for obstetric complications}

Postpartum data were entered for all study women from their medical histories. Birth weight and length were measured by the obstetric midwife attending the birth, while the condition of the newborn after delivery and Apgar score were given by the neonatologist.

Preterm delivery was defined as delivery before 37 completed gestational weeks. Intrauterine growth restriction (IUGR) was defined as birth weight less than $10^{\text {th }}$ percentile for gestational age. Low birth weight (LBW) was defined as weight equal to or less than 2,500 $\mathrm{g}^{7}$, while large for gestational age (LGA) was a newborn with weight $>4000 \mathrm{~g}$. Apgar score was considered if Apgar score at $1 \mathrm{~min}$ was less than $7^{8}$.

The aim of this study was twofold, i.e. first, to investigate whether IMH is associated with adverse pregnancy outcome in North Macedonia, and second, to compare adverse pregnancy outcomes between the $\mathrm{IMH}$ and normal thyroid function (NTF) groups.

This study was approved by the Ethics Committee of the School of Medicine, Ss. Cyril and Methodius University in Skopje at its $16^{\text {th }}$ session held on January 24, 2019 (no. 03-242/3). All procedures were performed in accordance with the 1975 Declaration of Helsinki and Directive 2001/20/EC of the European Parliament and Council of April 4, 2001.

\section{Statistical analysis}

Statistical analysis was performed using MedCalc Statistical Software version 19.1.3 (MedCalc Software bv, Ostend, Belgium; https://www.medcalc.org; 2019). Results were expressed as mean and standard deviation (SD) or median and interquartile range (IQR), 95\% confidence interval (CI) for median, $n$ (number) and \% (percent). We used Mann-Whitney U test or t-test for 
Table 1. Maternal characteristics, deliveries and fetal outcomes in study groups

\begin{tabular}{|c|c|c|c|}
\hline Group & $\begin{array}{l}\text { Normal thyroid function } \\
\mathrm{N}=218(62.28 \%)\end{array}$ & $\begin{array}{l}\text { Isolated } \\
\text { hypothyroxinemia } \\
\mathrm{N}=131(37.42 \%)\end{array}$ & $\mathrm{p}$ \\
\hline Gestational age at delivery (weeks) & $38.39 \pm 2.32$ & $38.46 \pm 2.92$ & 0.808 \\
\hline \multicolumn{4}{|l|}{ Mode of delivery: } \\
\hline Normal spontaneous delivery & $127(58.25)$ & $61(46.21)$ & 0.068 \\
\hline Cesarean section (CS) total & $91(41.74)$ & $70(53.03)$ & \\
\hline - CS for fetal distress & $23(25.27)$ & $10(7.57)$ & 0.323 \\
\hline - CS for dystocia/disproportion & $24(26.37)$ & $11(8.33)$ & 0.024 \\
\hline \multicolumn{4}{|l|}{ Fetal outcome: } \\
\hline Preterm birth & $28(12.84)$ & $13(9.84)$ & 0.448 \\
\hline Birth weight (g) & $3084.97 \pm 524.56$ & $3211.94 \pm 627.90$ & 0.043 \\
\hline IUGR & $9(4.12)$ & $3(2.27)$ & 0.028 \\
\hline LBW & $29(13.30)$ & $17(12.87)$ & 0.597 \\
\hline Apgar score $(1 \mathrm{~min})<7$ & $13(5.96)$ & $6(4.54)$ & 0.018 \\
\hline \multicolumn{4}{|l|}{ Maternal characteristics: } \\
\hline Median age (years) & 29 & 29 & 0.274 \\
\hline Median BMI $\left(\mathrm{kg} / \mathrm{m}^{2}\right)$ & 26.44 & 27.43 & 0.018 \\
\hline
\end{tabular}

Results are expressed as median, mean $\pm \mathrm{SD}, \mathrm{n}(\%)$, number (percent); BMI = body mass index; LBW = low birth weight; IUGR $=$ intrauterine growth restriction; $\mathrm{p}=$ level of statistical significance

independent samples to compare differences between two variables (non-normally or normally distributed). Backward multiple regression and logistic regression analysis was used to show predictable values of independent variables (continuous or categorical) and outcome, which is continuous or binary.

\section{Results}

\section{Demographic data}

Fetal outcomes and mother characteristics are summarized in Table 1. Of the total of 359 woman, 131 (37.42\%) women had IMH. The mean gestational age at delivery was similar in the two groups (38 weeks, $\mathrm{p}=0.808$ ). When comparing mother characteristics, maternal BMI was statistically significantly higher in the IMH group (median 27.43 vs. 26.44, $\mathrm{p}=0.018$ ). Compared to the NTF group, a significant increase in birth weight was noted in infants born to IMH mothers $(p=0.043)$. Three women with low TT4 levels in pregnancy gave birth to babies with IUGR. The prevalence of LBW infants in the two groups was $13.3 \%$ and $12.87 \%$, respectively, yielding no statistically significant difference $(\mathrm{p}=0.597)$.
The corresponding relative risk $(\mathrm{RR})$ for preterm delivery was 0.77 (95\% CI 0.41-1.43) and for LBW 0.97 (95\% CI 0.55-1.70), compared to RR for IUGR, which was 0.55 (95\% CI 0.15-2.01) and for Apgar score at $1 \mathrm{~min}<7$, which was 0.76 (95\% CI 0.29-1.97).

There was no age difference between the NTF and IMH groups (median age 29 both, $\mathrm{p}=0.274$ ). Concerning fetal outcomes, there were statistically significant differences between the NTF and IMH groups in birth weight ( $p=0.043)$, IUGR ( $p=0.028)$ and Apgar score at $1 \mathrm{~min}(\mathrm{p}=0.018)$. In maternal characteristics, there was a statistically significant difference in BMI between the NTF and IMH groups ( $\mathrm{p}=0.018$ ) (Table 1). Median BMI $\left(\mathrm{kg} / \mathrm{m}^{2}\right)$ was 26.44 in the NTF group and 27.43 in the IMH group. Obese woman had depressed TT4 range and were prone to hypothyroxinemia.

Median TSH was $0.500 \mathrm{mU} / \mathrm{L}$ in the NTF group and $0.400 \mathrm{mU} / \mathrm{L}$ in the $\mathrm{IMH}$ group, yielding a statistically significant difference $(\mathrm{p}=0.0121)$, as well as in TT4 (118.85 nmol/L vs. $79.9 \mathrm{nmol} / \mathrm{L}, \mathrm{p}=0.0001)$. Details on thyroid hormone levels, their IQR and 95\% CI for the cohort are shown in Table 2.

Median TSH (0.500 mU/L) and TT4 (118.85 $\mathrm{nmol} / \mathrm{L}$ ) values in the NTF group refer to a represen- 
Table 2. Maternal demographic and thyroid status according to thyroid function groups

\begin{tabular}{|c|c|c|c|c|c|}
\hline \multirow[b]{2}{*}{$\begin{array}{l}\text { Demographic } \\
\text { and thyroid } \\
\text { function values }\end{array}$} & \multicolumn{2}{|c|}{$\begin{array}{l}\text { Normal thyroid function } \\
\mathrm{N}=218\end{array}$} & \multicolumn{2}{|c|}{$\begin{array}{l}\text { Isolated hypothyroxinemia } \\
\mathrm{N}=131\end{array}$} & \multirow{2}{*}{$\begin{array}{l}\text { Mann-Whitney } \\
\text { t-test } \\
\text { p }\end{array}$} \\
\hline & $\begin{array}{l}\text { Median } \\
\left(25^{\text {th }}-75^{\text {th }} \text { percentile }\right) \\
\text { Mean } \pm \mathrm{SD}\end{array}$ & $\begin{array}{l}95 \% \mathrm{CI} \\
\text { for mean/ } \\
\text { median }\end{array}$ & $\begin{array}{l}\text { Median } \\
\left(25^{\text {th }}-75^{\text {th }} \text { percentile }\right)\end{array}$ & $\begin{array}{l}95 \% \mathrm{CI} \\
\text { for mean/ } \\
\text { median }\end{array}$ & \\
\hline Age (years) & $29.0 \pm 5.2$ & $28.30-29.69$ & $29.8 \pm 6.0$ & $28.81-30.88$ & 0.1633 \\
\hline $\mathrm{BMI}\left(\mathrm{kg} / \mathrm{m}^{2}\right)$ & $26.71 \pm 4.62$ & $26.09-27.32$ & $27.97 \pm 5.05$ & $27.09-28.84$ & 0.0176 \\
\hline $\mathrm{TSH}(\mathrm{mU} / \mathrm{L})$ & $0.500(0.400-0.700)$ & $0.500-0.595$ & $0.400(0.300-0.700)$ & $0.300-0.500$ & 0.0121 \\
\hline TT4 (nmol/L) & $118.85(104.8-133.9)$ & 115.5-120.79 & $79.9(66.2-91.65)$ & 75.64-83.87 & $<0.0001$ \\
\hline
\end{tabular}

Results are expressed as mean $\pm \mathrm{SD}$ (standard deviation), median, interquartile range $\left(25^{\text {th }}-75^{\text {th }}\right.$ percentile), $95 \%$ confidence interval $(95 \%$ $\mathrm{CI}$ ) for mean or median, number $(\mathrm{N})$ and $\mathrm{p}$-value; $\mathrm{p}=$ level of statistical significance; $\mathrm{BMI}=$ body mass index; $\mathrm{TSH}=$ thyroid stimulating hormone; TT4 = total thyroxine

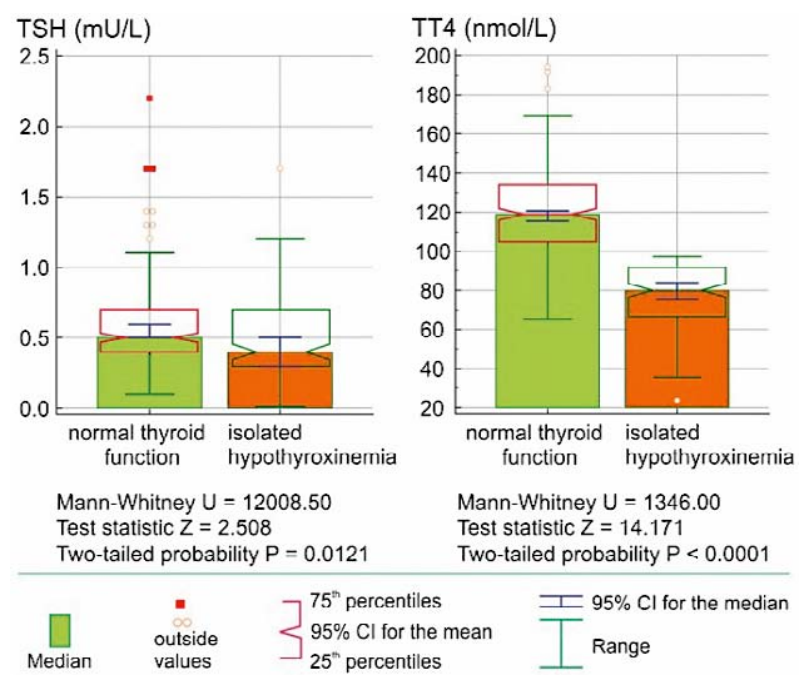

Fig. 1. Notched box-and-whisker plots of the median, $25^{\text {th }}$ and $75^{\text {th }}$ percentiles, 95\% confidence interval (CI) for the mean, 95\% CI for the median, and range for thyroid stimulating hormone (TSH) and total thyroxine (TT4) (Mann-Whitney U test).

tative sample of 218 patients. By interpreting their median values, we generalized that information to the overall statistical population with a safety threshold of 0.95 , claiming that the mean TSH and TT4 values would reach $0.500-0.595 \mathrm{mU} / \mathrm{L}$ and $115.5-120.79$ $\mathrm{nmol} / \mathrm{L}$, respectively. The results for age (years), BMI $\left(\mathrm{kg} / \mathrm{m}^{2}\right)$, TSH $(\mathrm{mU} / \mathrm{L})$ and TT4 $(\mathrm{nmol} / \mathrm{L})$ in both thyroid categorized groups are shown in Table 2 . Median TSH $(0.400 \mathrm{mU} / \mathrm{L})$ and TT4 $(79.9 \mathrm{nmol} / \mathrm{L}) \mathrm{val}-$ ues in the IMH refer to a representative sample of 131 patients. By interpreting their median values, we generalized that information to the overall statistical pop- ulation with a safety threshold of 0.95 , claiming that the mean TSH and TT4 values would reach 0.300 $0.500 \mathrm{mU} / \mathrm{L}$ and $75.64-83.87 \mathrm{nmol} / \mathrm{L}$, respectively.

We used Mann-Whitney U test to compare differences between the two independent groups (NTF and IMH) because the variables (TSH and TT4) were not normally distributed. The average rank was 185.4151 for TSH in the NTF group and 157.6679 for TSH in the IMH group. The result of Mann-Whitney U test was 12008.50 , test statistic $Z$ (corrected for ties) was 2.508 , and two-tailed probability $\mathrm{p}=0.0121$. The average rank was 234.3257 for TT4 in the NTF group and 76.2748 for TT4 in the IMH group. The result of Mann-Whitney U test was 1346.00 , test statistic Z (corrected for ties) was 14.171, and two-tailed probability $\mathrm{p}<0.0001$.

We found a statistically significant difference in BMI between the two categorized groups $(p=0.176)$. There were statistically significant differences in TT4 and TSH values between the NTF and IMH groups. The results of independent Mann-Whitney $U$ test and notched box-and-whisker bars for the measured thyroid function values of TSH and TT4 according to the two predetermined groups (NTF and IMH) are presented in Figure 1.

\section{Regression analysis}

Assessments (standardized coefficient $\beta$ ( $\beta$ st), standard error of $\beta$ st, $t$, VIF (variance inflation factor) and p-value of significance) of the multiple regression model and correlation coefficients (coefficient of determination $\mathrm{R}^{2}$ and multiple correlation coefficient) in the NTF and IMH groups are shown in Table 3. 
Table 3. Multiple and logistic regression analysis of determinants of perinatal outcomes

\begin{tabular}{|c|c|c|c|c|c|c|c|c|c|c|}
\hline \multicolumn{11}{|c|}{ REGRESSION ANALYSIS } \\
\hline \multicolumn{5}{|c|}{ Normal thyroid function } & & \multicolumn{5}{|c|}{ Isolated hypothyroxinemia } \\
\hline \multicolumn{11}{|c|}{ Multiple regression } \\
\hline Dependent 1 & \multicolumn{10}{|c|}{ Apgar score at $1 \mathrm{~min}$} \\
\hline Sample size & 218 & & & & & 131 & & & & \\
\hline \multicolumn{2}{|c|}{ Coefficient of determination $\mathrm{R}^{2}$} & 0.04323 & & & & 0.0661 & & & & \\
\hline \multicolumn{2}{|c|}{ Multiple correlation coefficient } & 0.2079 & & & & 0.2571 & & & & \\
\hline $\begin{array}{l}\text { Independent } \\
\text { variables }\end{array}$ & Bst Coeff. & Std. Error & $\mathrm{t}$ & VIF & $\mathrm{p}$ & Bst Coeff. & Std. Error & $\mathbf{t}$ & VIF & $\mathrm{p}$ \\
\hline Constant & 7.4418 & & & & & 8.2851 & & & & \\
\hline TSH (mU/L) & 0.1822 & 0.2133 & 0.854 & 1.018 & 0.394 & 0.05597 & 0.2791 & 2.005 & 1.019 & 0.047 \\
\hline TT4 (nmol/L) & -0.003837 & 0.002829 & -1.356 & 1.016 & 0.176 & 0.002208 & 0.00524 & 0.421 & 1.035 & 0.674 \\
\hline Age (years) & 0.02982 & 0.012204 & 2.476 & 1.027 & 0.014 & -0.01424 & 0.01417 & -1.005 & 1.11 & 0.317 \\
\hline $\operatorname{BMI}\left(\mathrm{kg} / \mathrm{m}^{2}\right)$ & -0.00895 & 0.01351 & -0.662 & 1.017 & 0.508 & -0.01955 & 0.01717 & -1.142 & 1.15 & 0.256 \\
\hline Dependent 2 & \multicolumn{10}{|c|}{ Birth weight } \\
\hline Sample size & 218 & & & & & 131 & & & & \\
\hline \multicolumn{2}{|c|}{ Coefficient of determination $\mathrm{R}^{2}$} & 0.07928 & & & & 0.05004 & & & & \\
\hline \multicolumn{2}{|c|}{ Multiple correlation coefficient } & 0.2816 & & & & 0.2237 & & & & \\
\hline $\begin{array}{l}\text { Independent } \\
\text { variables }\end{array}$ & 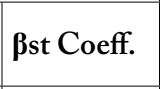 & Std. Error & $\mathbf{t}$ & VIF & $\mathrm{p}$ & Bst Coeff. & Std. Error & $\mathbf{t}$ & VIF & $\mathrm{p}$ \\
\hline Constant & 3.0626 & & & & & 2.5583 & & & & \\
\hline TSH (mU/L) & 0.11 & 0.1189 & 0.925 & 1.018 & 0.356 & 0.313 & 0.1886 & 1.660 & 1.019 & 0.099 \\
\hline TT4 (nmol/L) & -0.004778 & 0.001577 & -3.029 & 1.016 & 0.003 & 0.001759 & 0.00354 & 0.497 & 1.035 & 0.620 \\
\hline Age (years) & -0.003147 & 0.006715 & -0.469 & 1.027 & 0.640 & -0.009657 & 0.00957 & -1.009 & 1.11 & 0.315 \\
\hline $\mathrm{BMI}\left(\mathrm{kg} / \mathrm{m}^{2}\right)$ & 0.02331 & 0.007534 & 3.094 & 1.017 & 0.002 & 0.02338 & 0.01157 & 2.020 & 1.15 & 0.045 \\
\hline \multicolumn{11}{|c|}{ Logistic regression } \\
\hline Dependent 3 & \multicolumn{10}{|c|}{ Partus Prematurus Imminens (PPI): 1 - positive; 0 - negative } \\
\hline Sample size & \multicolumn{5}{|c|}{ Positive: 28 (12.84\%); Negative: 190 (87.16\%) } & \multicolumn{5}{|c|}{ Positive: 13 (9.92\%); Negative: 118 (90.08\%) } \\
\hline \multicolumn{11}{|c|}{ Coefficients and Standard Errors } \\
\hline Variable & Bst Coeff. & Std. Error & Odds ratio & Wald & $\mathrm{p}$ & Bst Coeff. & Std. Error & Odds ratio & Wald & $\mathrm{p}$ \\
\hline Constant & -4.6133 & 2.19866 & 1 & 4.4026 & 0.036 & -5.69027 & 2.89937 & 1 & 3.8518 & 0.049 \\
\hline $\mathrm{TSH}(\mathrm{mU} / \mathrm{L})$ & -1.06202 & 0.85085 & 0.3458 & 1.5580 & 0.212 & -0.41047 & 1.0973 & 0.6333 & 0.1399 & 0.708 \\
\hline TT4 (nmol/L) & 0.028112 & 0.009846 & 1.0285 & 8.1523 & 0.004 & 0.02524 & 0.02141 & 1.0256 & 1.39 & 0.238 \\
\hline Age (years) & 0.062743 & 0.04229 & 1.0648 & 2.2012 & 0.138 & -0.005364 & 0.05877 & 0.9947 & 1.2037 & 0.919 \\
\hline $\mathrm{BMI}\left(\mathrm{kg} / \mathrm{m}^{2}\right)$ & -0.07829 & 0.053226 & 0.9247 & 2.1636 & 0.141 & 0.064475 & 0.05877 & 1.0666 & 1.2037 & 0.273 \\
\hline Dependent 4 & \multicolumn{10}{|c|}{ SGA/IUGR: 1 -positive; 0 - negative } \\
\hline Sample size & Positive: 9 & $(4.13 \%) ; \mathrm{Ne}$ & gative: 209 (9 & $95.87 \%)$ & & Positive: 3 & $(2.29 \%) ; \mathrm{Ne}$ & rative: 128 (9 & $7.71 \%)$ & \\
\hline \multicolumn{11}{|c|}{ Coefficients and Standard Errors } \\
\hline Variable & 及st Coeff. & Std. Error & Odds ratio & Wald & $\mathbf{P}$ & Bst Coeff. & Std. Error & Odds ratio & Wald & $\mathbf{P}$ \\
\hline Constant & -1.2601 & 3.6773 & 1 & 0.117 & 0.732 & 10.79505 & 6.35612 & 1 & 2.8845 & 0.089 \\
\hline TSH (mU/L) & -0.21146 & 1.20242 & 0.8094 & 0.0309 & 0.860 & -4.12985 & 4.11427 & 0.0161 & 1.0076 & 0.315 \\
\hline TT4 (nmol/L) & -0.005648 & 0.016207 & 0.9944 & 0.1214 & 0.727 & -0.089834 & 0.04104 & 0.9141 & 4.7915 & 0.029 \\
\hline Age (years) & 0.02996 & 0.06628 & 1.0304 & 0.2043 & 0.651 & -0.20726 & 0.14909 & 0.8128 & 1.9326 & 0.164 \\
\hline BMI $\left(\mathrm{kg} / \mathrm{m}^{2}\right)$ & -0.076117 & 0.086722 & 0.9267 & 0.7704 & 0.380 & -0.057392 & 0.16456 & 0.9442 & 0.1216 & 0.727 \\
\hline
\end{tabular}

$\beta$ st Coeff. $=\beta$ standardized coefficient; Std. error = standard error; VIF = variance inflation factor; TSH = thyroid stimulating hormone; TT4 = total thyroxine; BMI = body mass index; SGA/IUGR = small for gestational age/intrauterine growth retardation 
Assessments ( $\beta$ st), standard error of $\beta$ st, odds ratio, WALD and p-value of significance) of the logistic regression model in the NTF and IMH groups are also shown in Table 3.

There was statistical significance of the $\beta$ st coefficient expressed by $\mathrm{p}$ value $(0.014)$ for age as an independent variable predicting Apgar score in the NTF group. Because of their positive correlation, any BMI increase resulted in increased Apgar score at $1 \mathrm{~min}$ only in NTF women, whereas TSH showed positive predicting value for Apgar score at $1 \mathrm{~min}(\mathrm{p}=0.047)$ in the IMH group.

There was an inverse correlation (negative $\beta$ st $=-$ 4.7779 coefficient) between TT4 and birth weight. This means that any reduction of maternal TT4 resulted in birth weight increase only in NTF women. BMI showed positive predictive value $(p=0.002$, $\mathrm{p}=0.045$ ) for birth weight in both study groups. In predicting preterm birth, we found a strong positive impact of TT4 $(\mathrm{p}=0.004)$ only in the NTF group, but an inverse impact (negative $\beta s t=-0.08934, p=0.029$ ) in the IMH group.

Based on their $\mathrm{e}^{\beta s t}$ value or $\exp \beta$ st ( $\mathrm{e}=$ natural logarithm) of regression $\beta$ st coefficients, in multiple regression analysis we calculated exp $(\beta s t)=1.030$ for maternal age in predicting Apgar score at $1 \mathrm{~min}$ in the NTF group and $\exp (\beta \mathrm{st})=1.057$ for TSH in predicting Apgar score at $1 \mathrm{~min}$ in the IMH group Each unit increase of maternal age resulted in 3.0\% rise in Apgar score at $1 \mathrm{~min}$ and each unit increase of TSH resulted in 5.7\% rise in Apgar score at $1 \mathrm{~min}$ in the NTF and IMH group, respectively.

In logistic regression analysis, we calculated $\exp (\beta s t)=1.028$ and $\exp (\beta s t)=-1.09399)$ for TT4 in predicting preterm birth in the NTF group and TT4 in predicting SGA/IUGR in the IMH group. Each unit increase of TT4 resulted in 2.8\% rise in the risk of preterm birth. Each unit increase of TT4 resulted in $9.39 \%$ decrease in the risk of SGA/IUGR.

\section{Discussion}

There are few studies that investigated IMH and adverse pregnancy outcomes. Available data are inconsistent, with conflicting results, but there is concern about the potential negative effects of early IMH on both the mother and the offspring.
In the study by Akbaba et al. ${ }^{9}$, which included 196 pregnant women from Turkey, IMH was detected in $38 \%$ of study women, which is similar to the results of our study, where we found IMH in $37.42 \%$ of the pregnant women from North Macedonia. Sufficient iodine intake is essentially important for the population, since iodine is the main constituent of thyroid hormones ${ }^{10}$. Our country, due to the longstanding and effective preventive measures, has been considered iodine replete since $2003^{11}$. So, in iodine-sufficient areas like this, the cause of IMH can be that pregnant women may not be consuming enough iodine daily (below the WHO recommended $250 \mu \mathrm{g} /$ day) required for normal production of thyroid hormones ${ }^{9,11}$. In the same study, there was no IMH woman detected in first trimester, whereas we recorded 4 such cases in first trimester. Akbaba et al. detected IMH in 32\% of $59 \mathrm{pa}-$ tients in second trimester, which is identical to our results on second trimester. In third trimester, they found IMH in 50 (27\%) of 185 women versus our result of $64.12 \%$ in third trimester'.

However, in the study by Kalampoki et al. ${ }^{12}$, hypothyroxinemia was associated with birth weight greater than $4000 \mathrm{~g}$, a finding similar to ours, showing that women with hypothyroxinemia give birth to heavier babies than euthyroid ones, with a statistically significant difference between the NTF and IMH groups $(\mathrm{p}=0.043)$ in our study. According to $\beta$ st coefficients in our study, we believe that birth weight would increase by $2.35 \%$ and $2.36 \%$ for every unit increase of maternal BMI in the NTF and IMH groups, respectively. Also, birth weight would decrease by $0.482 \%$ for every unit increase of TT4 in the NTF group $(\mathrm{p}=0.023)$. The correlation between birth weight and TT4 in the IMH group was not statistically significant $(\mathrm{p}=0.620)$.

And the last but not the least, Casey et al. ${ }^{13}$ showed that IMH in the first half of pregnancy had no effect on perinatal outcomes, just like our study results where there were no neonates with Apgar score at $1 \mathrm{~min}<7$, or IUGR, LBW, or preterm births in first trimester of IMH pregnancy. Casey et al. analyzed 233 women and found no excessive adverse pregnancy outcomes in women who had IMH in the first half of pregnancy ${ }^{13}$. The results of our study showed a strong statistically significant $(\mathrm{p}=0.029)$ inverse correlation between TT4 and SGA/IUGR only in the IMH group. The negative $\beta$ st result and $\exp (\beta s t)=-1.09399$ for TT4 in predicting SGA/IUGR showed that each unit increase of 
TT4 resulted in $9.39 \%$ decrease in the risk of SGA/ IUGR. In other words, crucial results of regression analysis of determinants of perinatal outcomes in the IMH group were strong positive predictive impact of TSH on Apgar score at $1 \mathrm{~min}$, strong positive predictive impact of BMI on birth weight, and inverse predictive impact of TT4 on SGA/IUGR.

Our findings demonstrated overweight to be a risk factor for hypothyroxinemia in pregnancy, similar to the study by Furnica et al. ${ }^{1}$. The prevalence of IMH was increased among pregnant women with BMI $>24$ $\mathrm{kg} / \mathrm{m}^{2}$. It is thought that obesity stimulates peripheral deiodinase activity as an adaptation process to increase energy expenditure, resulting in an increased conversion of FT4 to FT3, and weight loss has been shown to be associated with changes in thyroid hormone levels, including decreases in FT3 level ${ }^{14}$.

In many studies, elevated BMI was found in pregnant women with hypothyroxinemia ${ }^{5,14,15}$. A Chinese study found that BMI $\geq 25 \mathrm{~kg} / \mathrm{m}^{2}$ may act as an indicator of hypothyroxinemia ${ }^{5}$. Korevaar et al. also suggest that higher BMI might lead to lower thyroid function capacity $^{16}$. In our study, pregnant women with IMH had higher BMI (27.43 vs. $\left.26.44 \mathrm{~kg} / \mathrm{m}^{2}\right)$ than women with normal thyroid function ( $\mathrm{p}=0.018$ ).

Korevaar et al. showed that IMH women had a 2.5 -fold increased risk of premature delivery ${ }^{16}$. In contrast, our study did not reveal any association with this complication, just like the study by Furnica et al. ${ }^{1}$, or a statistically significant difference between NTF and IMH groups ( $p=0.448$ ). Contrary to this, a study conducted in a large Dutch pregnancy cohort, where the effects of thyroid dysfunction on the risk of premature delivery were investigated, showed that IMH was associated with an increased risk of premature delivery. Among the many endpoints studied, only the risk of abruptio placentae was found to be 2.3 times increased in mothers with IMH $(p=0.026)^{4}$. Nonetheless, the ATA guidelines do not currently recommend treatment of $\mathrm{IMH}^{6}$, while the recent European Endocrine Society guidelines leave it to the discretion of the care giver $^{17,18}$.

Our study had several strengths. First, none of the $\mathrm{IMH}$ women was prescribed levothyroxine, so a bias regarding the treatment of hypothyroxinemia could be excluded. A large sample size was another advantage of this study. Besides these strengths, our study also had some limitations. First, we did not evaluate thy- roid peroxidase antibodies or thyroglobulin antibodies, which are also connected to negative neonatal outcomes. Although the association between IMH and iodine deficiency is still controversial, another limitation of the study was that we did not measure urinary iodine level.

In conclusion, the definition and impact of hypothyroxinemia in pregnancy remain controversial. The prevalence of IMH during pregnancy was of $37.42 \%$ in our unselected Macedonian population of pregnant women. IMH was associated with an increased maternal BMI and higher neonatal birth weight. Overweight could be a potential risk factor for thyroid dysfunction in pregnant women, in particular hypothyroxinemia. Also, the worst fetal outcome (LBW, preterm delivery, and Apgar score at $1 \mathrm{~min}<7$ ) was recorded in IMH mothers examined in second trimester. Isolated hypothyroxinemia is a variable magnitude, caught at one point of intersection and may not persist throughout pregnancy, so it would not be a significant predictor of perinatal outcome. It has greatest impact on babies with higher birth weight and occurs in obese mothers. Concerning strong correlation of the thyroid parameters of TSH and TT4, and maternal BMI, they may be used as predictors of some perinatal outcomes (Apgar score at $1 \mathrm{~min}$, birth weight, and SGA/IUGR) in women with isolated hypothyroxinemia.

\section{References}

1. Furnica RM, Lazarus JH, Gruson D, Daumerie C. Update on a new controversy in endocrinology: isolated maternal hypothyroxinemia. J Endocrinol Invest. 2015;38(2):117-23. https:// doi.org/ 10.1007/s40618-014-0203-5.

2. Stagnaro-Green A, Abalovich M, Alexander E, Azizi F, Mestman J, et al. Guidelines of the American Thyroid Association for the diagnosis and management of thyroid disease during pregnancy and postpartum. Thyroid. 2011;21(10):1081-25. https://doi.org/ 10.1089/thy.2011.0087.

3. Gong X, Liu A, Li Y, Sun H, Li Y, et al. The impact of isolated maternal hypothyroxinemia during the first and second trimester of gestation on pregnancy outcomes: an intervention and prospective cohort study in China. J Endocrinol Invest. 2019; 42(5):599-607. https://doi.org/ 10.1007/s40618-018-0960-7.

4. Dosiou C, Medici M. Management of endocrine disease: isolated maternal hypothyroxinemia during pregnancy: knowns and unknowns. Eur J Endocrinol. 2017;176(1):R21-R38. https://doi.org/10.1530/EJE-16-0354.

5. Han C, Li C, Mao J, Wang W, Xie X, et al. High body mass index is an indicator of maternal hypothyroidism, hypothyrox- 
inemia, and thyroid-peroxidase antibody positivity during early pregnancy. BioMed Res Int. 2015;(351831):1-7. https://doi. org/10.1155/2015/351831.

6. Alexander E, Pearce E, Brent G, Brown SR, Chen H, Dosiou C, et al. Guidelines of the American Thyroid Association for the Diagnosis and Management of Thyroid Disease during Pregnancy and the Postpartum. Thyroid. 2017;27(3):315-89. https://doi.org/10.1089/thy.2016.0457.

7. World Health Organisation (WHO). International Statistical Classification of Diseases and Related Health Problems, $10^{\text {th }}$ revision. 2010, Vol. 2.

8. American College of Obstetrician and Gynecologists. The Apgar score. Committee Opinion Number 644. Obstet Gynecol. 2015;126(4):e52-5. https://doi.org/10.1097/AOG.000000000 0001108 .

9. Akbaba G, Akbaba E, Berker D, Isik S, Dogan B, et al. Fetalmaternal outcomes of isolated hypothyroxinemia in pregnancy. Turk Jem. 2014;18:106-10. https://doi.org/10.4274/tjem.2520.

10. Jukic T, Zimmermann MB, Granic R, Prpic M, Krilic D, Juresa $\mathrm{V}$, et al. Sufficient iodine intake in schoolchildren from the $\mathrm{Za}^{-}$ greb area: assessment with dried blood spot thyroglobulin as a new functional biomarker for iodine deficiency. Acta Clin Croat. 2015;54:424-31.

11. Majstorov V, Miladinova D, Kuzmanovska S, Itterman T, Pop Gjorcheva $\mathrm{D}$, et al. Schoolchildren thyroid volume in North Macedonia: data from a national survey in an iodine-sufficient country. J Endocrinol Invest. 2020;43(8):1073-9. https://doi. org/10.4274/tjem.2520.10.1007/s40618-020-01189-6.

12. Kalampoki L, Tsanadis G, Stefos, T. Subclinical hypothyroidism and isolated hypothyroxinemia during pregnancy and their association with pregnancy outcome: a 2-year study. Open J Obstet Gynecol. 2017;7:693-701. https://doi.org/10.4236/ ojog.2017.77069.

13. Casey BM, Dashe JS, Spong CY, McIntire DD, Leveno KJ, et al. Perinatal significance of isolated maternal hypothyroxinemia identified in the first half of pregnancy. Obstet Gynecol. 2007;109(5):1129-35. https://doi.org/10.1097/01.AOG.0000 262054.03531.24.

14. Sanyal D, Raychaudhuri M. Hypothyroidism and obesity: an intriguing link. Indian J Endocrinol Metab. 2016;20(4):554-7. https://doi.org/10.4103/2230-8210.183454.

15. Gowachirapant S, Melse-Boonstra A, Winichagoon P, Zimmermann MB. Overweight increases risk of first trimester hypothyroxinaemia in iodine-deficient pregnant women. Matern Child Nutr. 2014;10(1):61-71. https://doi.org/ 10.1111/ mcn.12040.

16. Korevaar TI, Schalekamp-Timmermans S, de Rijke YB, Visser WE, Visser W, et al. Hypothyroxinemia and TPO-antibody positivity are risk factors for premature delivery: the generation R study. J Clin Endocrinol Metab. 2013;98(11):4382-90. https://doi.org/ 10.1210/jc.2013-2855.

17. Lazarus J, Brown RS, Daumerie C, Hubalewska-Dydejczyk A, Negro R, et al. European Thyroid Association Guidelines for the management of subclinical hypothyroidism in pregnancy and in children. Eur Thyroid J. 2013;3(2):76-94. https://doi. org/10.1159/000362597.

18. Abalovich M, Amino N, Barbour LA, Cobin R.H, De Groot LJ, et al. Management of thyroid dysfunction during pregnancy and postpartum: an Endocrine Society Clinical Practice Guideline. J Clin Endocrinol Metab. 2007;92(8):S1-S47. https://doi.org/ 10.1210/jc.2007-0141.

Sažetak

\title{
IZOLIRANA HIPOTIROKSINEMIJA MAJKE I PERINATALNI ISHOD U SJEVERNOJ MAKEDONIJI
}

\author{
M. Avramovska, B. Karanfilski, G. Dimitrov, E. Dzikova, A. Daneva Markova, M. Hadzi Lega, G. Tofoski i A. Sikole
}

Izolirana hipotiroksinemija majke (IMH) je prisutnost niske koncentracije ukupnog tiroksina (TT4) u majke u kombinaciji s normalnim majčinim hormonom za stimulaciju štitnjače (TSH). Cilj naše studije bio je istražiti je li IMH povezan sa štetnim ishodom trudnoće u Sjevernoj Makedoniji.U 359 trudnica koje su zadovoljile kriterije uzeti su uzorci osušene kapi krvi koji su analizirani na TT4 i TSH. Podaci nakon porođaja uneseni su za svaku majku iz njihove povijesti bolesti. Od ukupno 359 žena $131(37,42 \%)$ je pripadala skupini IMH. Utvrđene su statistički značajne razlike u porođajnoj težini $(\mathrm{p}=0,043)$, intrauterinom ograničenju rasta (IUGR) $(\mathrm{p}=0,028)$, Apgar zbroju u 1 . minuti $<7(\mathrm{p}=0,018)$ i carskom rezu zbog distocije/disproporcije ( $\mathrm{p}=0,024)$ između skupina s IMH i s normalnom funkcijom štitnjače (NFŠ). U regresijskoj analizi TSH je bila značajna varijabla za predviđanje Apgar zbroja ( $\beta s t=0,05597, p=0,047)$, indeks tjelesne mase (ITM) za predviđanje porođajne težine $(\beta s t=0,02338, p=0,045)$ i TT4 za predviđanje rođenja djeteta malog za gestacijsku dob/IUGR $(\beta s t=-0,089834, p=0,029)$ u skupini IMH.TT4 je bio snažni prediktor porođajne težine $(\beta s t=-0,004778, p=0,003)$ i prijevremenog porođaja $(\beta s t=0,028112, p=0,004)$ u skupini NTF. Učinak IMH u trudnoći i dalje je proturječan. IMH je bio povezan s povećanim ITM majke i većom težinom novorođenčeta. Prekomjerna težina može biti potencijalni čimbenik rizika za disfunkciju štitnjače u trudnica, osobito IMH. Najgori fetalni ishod bio je kod majki s IMH koje su ispitane u drugom tromjesečju. TSH, TT4 i ITM snažni su prediktori za perinatalni ishod.

Ključne riječi: Izolirana hipotiroksinemija; Perinatalni ishod; Mala porođajna težina; Prijevremeni porođaj; Pretilost 